32. Петров С.М. Неутомимый исследователь // Здоровье. 1957. № 3. С. 7-8.

33. Навашин С.М. Новая эра в медицине // Здоровье. 1966. № 3. С. 2-3.

34. Соловьев В.Д., Бектимиров Т.А. Интерферон в теории и практике медицины. М.: Медицина, 1970. $272 \mathrm{c}$.

35. Трусле Э.А., Дук А.Э., Смилга Я.М. Взаимосвязь между образованием интерферона и специфическим иммунитетом // Индукция и действие интерферона. Рига: Зинатне, 1975. С. 120-135.

36. Бостанджян М.Г., Фадеева Л.Л. Невирусные индуценты интерферона. Ереван: Айастан, 1975. 116 с.
37. К 45-летию научной, педагогической и общественной деятельности 3.В. Ермольевой // Антибиотики. 1969. Т. XIV, № 4. С. 291-293.

38. 3.В. Ермольева (к 50-летию научной, педагогической и общественной деятельности) // Антибиотики. 1974. Т. ХIX, № 2. С. 185-186.

39. Жизнь в науке (к 75-летию со дня рождения 3.В. Ермольевой) // Журнал микробиологии, эпидемиологии и иммунобиологии. 1973. № 12. С. 127-128.

40. Памяти Зинаиды Виссарионовны Ермольевой // Антибиотики. 1975. Т. ХХ, № 3. С. 281-282.

41. Мельникова Т.Л. Сквозь завесу невидимого. Волгоград: Ниж.-Волж. кн. изд-во, 1984. 79 с.

\title{
THE HISTORY OF MICROBIOLOGIST Z.V. ERMOLEVA'S SCIENTIFIC ACTIVITY: A BRIEF OVERVIEW OF SOVIET HISTORIOGRAPHY
}

(C) 2019

\author{
Gorshenin Aleksandr Vladimirovich, candidate of historical sciences, \\ associate professor of the Humanities Department \\ Medical University «Reaviz» (Samara, Russian Federation)
}

Abstract. The paper attempts to analyze the key lines of the soviet historiography in the coverage of scientific and organizational activities of Zinaida Vissarionovna Ermoleva, as well as to characterize the degree of information content of publications on the problem. Z.V. Ermoleva (1898-1974) is a famous soviet medical scientist, a microbiologist and a bacteriogenic, a winner of the Stalin prize I degree, an honored worker of science of Russian Soviet Federative Socialist Republic, a professor, a doctor of medical sciences, an academician of the Academy of Medical Sciences of the USSR. Her scientific and practical activities helped to save thousands of people from death. One of the most famous achievements of Z.V. Ermoleva was the invention of the first domestic antibiotic - «penicillinkrustosin» and the establishment of its industrial production in the harsh years of the Great Patriotic War. There were also numerous works on the study of cholera vibrions, interferon, lysozyme, various types of antibiotics and their combinations. Z.V. Ermoleva's life as well as the history of her research activities are not well reflected in scientific literature. Unfortunately, no historiographical work has been published on the history of this amazing woman scientist. This historiographical review is not exhaustive; it should be perceived as a ground for a further study of her scientific work. Due to the specificity of the subject under consideration, the historiographical review is based on the problem principle.

Keywords: Zinaida Vissarionovna Ermoleva; scientists; historiography; history of science; history of medicine; Great Patriotic War; cholera; penicillin; bacteriophage; lysozyme; interferon; epidemic; microbiology; antibiotics; sanitary conditions; women doctors of science; women scientists in USSR.

$* * *$

УДК 930

DOI 10.24411/2309-4370-2019-14217

Статья поступила в редакцию 15.09 .2019

\section{РЕВОЛЮЦИЯ И ГРАЖДАНСКАЯ ВОЙНА В РОССИИ В КАНАДСКОЙ ИСТОРИОГРАФИИ}

(C) 2019

Бандилет Сергей Викторович, аспирант департамента истории и археологии Дальневосточный федеральный университет (2. Владивосток, Российская Федераиия)

Аннотация. В статье рассматривается восприятие Февральской и Октябрьской революций, а также Гражданской войны в историографии Канады. Под последней понимаются, во-первых, труды историков - граждан Канады, во-вторых - труды учёных из других стран, работавших в Канаде долгое время, и, наконец, труды иностранцев, опубликованные в канадских научных журналах. Работы канадских историков-русистов по рассматриваемой теме можно разделить на три группы. Во-первых, это фундаментальные труды по истории Революции и Гражданской войны. Во-вторых, это труды, посвященные иностранной интервенции в Россию и участию Канады в ней. В-третьих, это труды, касающиеся прочих частных аспектов рассматриваемой темы. Авторы всех рассмотренных работ относятся к Февральской революции как к важному для России шагу к демократии. Октябрьскую революцию канадская историография в основном осуждает, а ее организаторы, большевики, критикуются за авторитаризм и радикализм. Что касается белогвардейцев, то к ним отношение у канадских ученых неоднозначное. С одной стороны, присутствует определенная симпатия к белым как к союзникам Антанты (в которую входила и Канада), но с другой - белые осуждаются за непродуманную внутреннюю политику, а также за невозможность достичь компромисса друг с другом. Тема канадской историографии событий 19171922 гг. в России на данный момент практически не исследована и посему представляет научный интерес.

Ключевые слова: Канада; историография; Февральская революция; Октябрьская революция; большевики; Гражданская война в России; Иностранная интервенция в России; Антанта; Канадская сибирская экспедиция; Канадский сибирский экспедиционный корпус; Сибирь; Колчак; Омское правительство; Брестский мир. 
В 2017 году в России широко отмечалась столетняя годовщина Февральской и Октябрьской революций, а в 2018 году - столетие со времени начала Гражданской войны в России. Безусловно, события 1917-1922 гг. в России, один из наиболее сложных и проблемных периодов российской истории, всегда привлекали внимание не только отечественных, но и зарубежных ученых. Не стали в этом отношении исключением историки такой, казалось бы, далекой от нас страны, как Канада. Данная статья посвящена тому, как вышеуказанные события воспринимались в канадской историографии. Под последней в рамках статьи понимаются, во-первых, труды историков граждан Канады, во-вторых - труды учёных из других стран, работавших в Канаде долгое время, и, наконец, труды иностранцев, опубликованные в канадских научных журналах.

На данный момент восприятие Революции и Гражданской войны в России в историографии Канады, в отличие от такового в англо-американской историографии (см., например [1]), пока не было предметом специального изучения в исторической науке, как в отечественной, так и в зарубежной. Относительно исследованным является только один аспект этой темы - историография участия канадского военного контингента в интервенции на русском Севере в 1918-1919 гг., чему посвящена одноименная статья А.В. Неровного [2, с. 1004-1018]. Прочие аспекты данной темы пока остаются неисследованными. Это и придает актуальность настоящей статье.

Начать обзор канадской историографии по данной теме стоит, пожалуй, с первой в Канаде фундаментальной работы, посвященной событиям 19171922 гг. в России. Это монография Дж. Мейвора «The Russian Revolution», впервые изданная в 1928 г. [3]. Как историк экономики, Мейвор делает основной упор именно на экономический аспект, рассматривая события политической и военной истории лишь в той мере, в какой они связаны с ходом экономического развития. Ученый начинает свою книгу с подробного рассмотрения состояния российской экономики до Первой мировой войны, а также влияния войны на экономику царской России. Это не случайно, так как основной причиной революции Мейвор считает именно экономические последствия войны [3, book I, ch. I-III]. К большевикам Мейвор, убежденный антикоммунист, относится критично. Однако он отдает им должное, замечая, что большевики обладали тремя незаменимыми для достижения власти качествами: решительностью, приспособляемостью и способностью идти на тактические уступки [3, book IV, ch. I]. Политику большевиков, в особенности экономическую, ученый резко критикует, но признает их успехи в отдельных областях - в частности, в культурной работе с населением и в ликвидации неграмотности. Мейвор считает, что хоть РКП(б) и позиционировала себя как партия рабочего класса, при большевистском режиме положение рабочих стало более тяжелым, чем при царизме - они фактически превратились в бесправную массу [3, book IV, ch. I]. Рассматривая Гражданскую войну, Мейвор опять отдает должное большевикам, считая, что на контролируемой ими территории они хотя бы делали попытки организации экономической жизни (в частности, решения земельного вопроса), в отличие от белых, которые откладывали этот вопрос до созыва Учредительного собрания [3, book III, ch. IX].
Работа Мейвора получила в основном негативные отзывы рецензентов, которые обвиняли автора в необъективности по отношению к большевикам [4, p. 279; 5, p. 452-473]. Дж. Смил, автор лучшей на сегодняшний день аннотированной библиографии по теме Революции и Гражданской войны, отмечает, что в настоящее время книга Мейвора устарела $[6$, p.65]. Тем не менее она имеет историческую ценность как первая канадская фундаментальная работа о событиях 1917-1922 гг.

В современной Канаде виднейшим специалистом по истории Революции и Гражданской войны в России является Н.Г.О. Перейра, специализирующийся на истории Сибири в этот период. Его перу принадлежит монография 1996 г. «White Siberia: The Politics of Civil War» [7], одна из лучших канадских монографий по рассматриваемой теме. В этой работе Перейра рассматривает внутреннюю политику сменявших друг друга белых правительств Сибири - правительства Дербера, Уфимской директории и правительства Колчака. Особое внимание ученый обращает внимание на региональные особенности Сибири, а также на менталитет сибирского крестьянства: эти факторы, по его мнению, оказывали большое влияние на внутреннюю политику сибирских правительств. Работа Н.Г.О. Перейры, прекрасно владеющего русским языком, написана с опорой на большое число русскоязычных источников, включая газеты и мемуары политических деятелей.

Достоинством данной работы является относительная нейтральность: автор беспристрастно относится к большинству событий и деятелей Гражданской войны в Сибири. Единственная фигура, которую Перейра активно критикует, - это адмирал Колчак. Автор описывает Колчака как нетерпимого к критике, низкоинтеллектуального человека, склонного перепоручать дела подчиненным (что вело к самоуправству и коррупции на местах) [7, с. 110]. Политическую атмосферу в колчаковском Омске Перейра характеризует как «нереально шовинистическую» [7, с. 112], а сам омский режим - как «беспорядок, цинизм и чудовищную коррупцию» [7, c. 130]. Критика Колчака Перейрой достаточно эмоциональна, но, в основном, справедлива.

В своей работе Перейра, как справедливо отметила В.Ю. Минаева, не пытается оправдать интервенцию, что, безусловно, является достоинством книги [8]. Он признает, что Антанта сыграла большую роль в вооружении и снабжении армии Колчака и что помощь Антанты оказала положительное влияние на моральный дух колчаковцев, однако все же не считает вклад интервентов в Гражданскую войну решающим [7, с. 172]. По мнению Перейры, белые были обречены на поражение. Главной причиной последнего было то, что они не смогли дать населению четкой позитивной программы, ограничившись лишь критикой большевизма [7, с. 172-174]. Что касается основной причины победы красных, то ею ученый считает менталитет русского крестьянства, его страх перед ответственностью, привычку перекладывать ее на власти. Красные олицетворяли для крестьян сильную власть, которая сможет вступиться за них, обеспечить их безопасность и защиту их интересов [7, c. 169-171]. Наконец, еще одной причиной успеха большевиков в Сибири Перейра видит то, что омский режим дискредитировал себя в глазах большинства сибиряков, в частности - в глазах крестьян, про- 
блемы которых Колчаком игнорировались [7, с. 167]. Поэтому в красных сибиряки видели в первую очередь освободителей от колчаковского беззакония. Последствия Гражданской войны Перейра оценивает однозначно негативно: ценой победы большевиков стало, по мнению ученого, установление в России диктатуры и многолетнее отставание ее от Запада в плане развития политической культуры.

Упомянутая монография стала завершением многолетней работы Перейры по исследованию Гражданской войны в Сибири. До ее публикации, в конце 1980-х - начале 1990-х гг. он написал ряд статей по этой теме, достойных упоминания. Можно назвать его статью о режиме Колчака в журнале Canadian Slavonic Papers за 1988 г., в которой ученый подробно останавливается на причинах падения режима. Он отмечает, что омское правительство провалило абсолютно все стоявшие перед ним задачи, как внутриполитические (обеспечение своей легитимности), так и внешнеполитические (получение признания Антантой), что и привело режим к краху [9]. Интересны две статьи Перейры, посвященные идеологии сибирского областничества в годы Революции и Гражданской войны $[10 ; 11]$. Стоит назвать и статью о партизанском движении в Западной Сибири в 1918 1920 гг. Перейра считает, что партизанские отряды в Гражданской войне создавались стихийно, самими крестьянами, понимавшими, что только они сами могут защитить себя, свои интересы от произвола государственной власти [12]. Дж. Смил отмечает, что в этом его концепция идет вразрез с точкой зрения, принятой как в советской (где считалось, что партизаны действовали под руководством компартии), так и в западной историографии [6, р. 523]. Наконец, можно отметить главу об атамане Г. Семенове, которую Перейра написал для коллективной монографии «The Bolsheviks in Russian Society: The Revolution and the Civil Wars». Эта глава в основном посвящена сложным отношениям Семенова и Колчака. Перейра называет их конфликт «политическим центрифугированием» и отмечает, что он разрушил и без того хрупкий баланс сил в лагере белых, что способствовало росту влияния большевиков [13].

Еще одним крупным канадским специалистом по истории России является Д. Марплз, профессор Университета Альберты. В рамках рассматриваемой темы интересна его монография «Motherland: Russia in the Twentieth Century», которая посвящена истории России в XX в. Как и Дж. Мейвор, Марплз считает главной причиной революции экономические и социальные последствия Первой мировой войны [14, p. 20]. Ученый хорошо отзывается о Февральской революции и ее последствиях - ему импонируют демократические мероприятия Временного правительства, таких как введение 8-часового рабочего дня и всеобщая амнистия $[14$, p. 22]. Что касается Октябрьских событий, то их Марплз оценивает гораздо более скептично. К В.И. Ленину он относится отрицательно, называя его «фанатиком», однако признавая за ним большой талант организатора масс и признавая, что Октябрьский переворот был «хорошо спланирован» [14, p. 31]. Также канадский ученый считает, что при желании большевики, учитывая их популярность в 1917 г., могли бы прийти к власти демократическим путем, однако они осознанно предпочли насильственный путь к власти $[14$, с. 31$]$. Стоит отметить и то, что, в отличие от большинства других канадских историков, Марплз не осуждает большевиков за подписание Брестского мира, а оправдывает их тем, что мир был необходим для выживания большевистского государства. Критикует он лишь Л.Д. Троцкого за его позицию «ни мира, ни войны, а армию распустить» $[14$, р. 52]. Одной из важнейших причин Гражданской войны он считает политику военного коммунизма, в особенности деятельность комбедов: эта политика, по мысли автора, оттолкнула от большевиков основную массу крестьян [14, p. 62-63]. Главными причинами поражения белых Марплз считает следующие: во-первых - разобщенность, отсутствие единого командования, во-вторых - оторванность от интересов простого народа [14, p. 67], в-третьих - провозглашение ими лозунга «Единой и неделимой России», который был неприемлем для национальных меньшинств, желавших автономии или независимости $[14$, р. 68]. Особое внимание в своей работе Марплз, который также является специалистом по истории Украины и Белоруссии, уделяет ходу революции в этих странах. Как и многие другие канадские историки, он поддерживает концепцию отдельной Украинской революции 19171921 гг., не принятую в отечественной историографии [14, p. 43-57, 57-58].

Говоря о канадской историографии Революции и Гражданской войны, нельзя не упомянуть проживающего с 1995 г. в Монреале нашего бывшего соотечественника Г.3. Иоффе, в советское время - автора нескольких монографий по рассматриваемой теме. В канадский период им была написана, в частности, статья «Долой временное правительство!», в которой он прослеживает судьбы министров Временного правительства после его свержения [15]. В 2017 г. на прошедшей в Санкт-Петербурге международной конференции «Основные проблемы историографии Февральской революции в вопросах и ответах» Иоффе детально обосновал свою позицию по событиям 1917 г. По его мнению, участие России в Первой мировой войне мало повлияло на приход революции, ибо последняя была неизбежна - из-за падения престижа монархии, подорванного распутинщиной. Главную роль в падении монархии Иоффе отдает Временному комитету Государственной думы и генералитету, а не народным массам. Октябрьскую революцию ученый рассматривает как органическое продолжение Февральской, предлагая оценивать их значение совместно. По его мнению, Февраль установил в стране демократию, но не устранил тягу русских к «сильной руке», которая и была реализована в Октябре. Последнее, как думает Иоффе, также было ожидаемо, так как «беспредельная демократия вела к развалу армии и грозила распадом страны» [16].

Далее стоит сказать об одном из самых изученных в канадской историографии аспектов Гражданской войны в России - истории пребывания в нашей стране частей Канадского Сибирского экспедиционного корпуса (КСЭК). Пока единственной работой по теме КСЭК, изданной на русском языке (и, в принципе, одной из немногих канадских работ о Революции и Гражданской войне, изданных на русском) является монография Б. Айситта «Из Виктории во Владивосток: Канадская Сибирская экспедиция 1917-1919» [17]. Как верно отмечает К.С. Еременко, книга Айситта посвящена не столько военной, сколько социальной истории Канады и России [18]. Айситт делает акцент не на боевом пути солдат 
КСЭК (которого у них и не было - части КСЭК в Приморье не участвовали в боях, их использовали для охраны складов и в качестве полицейских), а на их повседневной жизни и на восприятии ими событий Гражданской войны. Основной причиной иностранной интервенции, по мнению Айситта, стало нарушение Россией союзнических обязательств перед Антантой - заключение сепаратного мира с Германией. Главными же причинами участия Канады в интервенции Айситт считает три. Во-первых, это желание позиционировать себя как отдельную от Великобритании силу, во-вторых - стремление получить контроль над сибирскими природными ресурсами и над торговым домом «Кунст и Альберс» и в-третьих - желание решить с помощью «маленькой победоносной войны» внутренние проблемы, такие как недовольство введенным в 1917 г. призывом в армию. Ученый также отмечает четвертую причину стремление Великобритании вернуть взятые царским правительством займы, к которому Канада присоединилась не по своей воле, а как часть Британской империи $[17$, с. $32-35]$. В своей книге Айситт показывает непонимание и неприятие целей интервенции простыми канадцами и, как следствие, - нежелание канадцев служить в КСЭК и сражаться с большевиками, отсутствие у них враждебности к русским. К недостаткам русского перевода книги Айситта можно отнести большое число неточностей в транслитерации английских и французских имен собственных, а также ряда терминов. Например, написание «вицегубернатор» вместо «лейтенант-губернатор» [17, c. 323] (что полностью искажает смысл фразы, ибо вице-губернатор - это заместитель главы административной единицы, а лейтенант-губернатор в Канаде - собственно ее глава), «Новый Браннсвик» вместо «Нью-Брансуик» [17, с. 14], передача фамилии автора книги Isitt как «Иситт» вместо «Айситт», фамилии солдата КСЭК, впоследствии известного актёра Р. Мэсси (Massey) как «Сассей» [17, с. 117], фамилии канадского политика Н. Рауэлла (Rowell) как «Ровел» $[17$, с. 30$]$ и «Ровель» $[17$, с. 33] и т.д. Еще один значимый недочет - отсутствие перевода на русский язык части примечаний при том, что другая их часть переведена [18, с. 111]. Несмотря на это, русский перевод книги Айситта имеет огромную научную ценность. Данная монография является уникальной тем, что позволяет взглянуть на нашу Гражданскую войну со стороны, глазами простого канадского солдата-наблюдателя, как правило, нейтрального и беспристрастного в отношении воюющих сторон. Плюс, как уже отмечалось, это одна из немногих англоязычных монографий по рассматриваемой теме, переведенных на русский язык.

Другая крупная монография по теме КСЭК - работа канадского историка, политика и дипломата Р. Макларена «Canadians in Russia 1918-1919» [19]. Здесь, в отличие от книги Айситта, упор делается именно на военную историю КСЭК. Главное внимание автор уделяет пути канадских частей по России, их взаимодействию с британскими и белогвардейскими войсками. Монография Макларена наиболее полно охватывает все театры военных действий, где находились канадцы: он пишет не только о пребывании КСЭК во Владивостоке [19, p. 9-36], но и о его участии в интервенции на Севере России $[19$, р. $37-$ 54] и в Прикаспии [19, р. 125-215].

Среди других работ по теме КСЭК стоит назвать две статьи, подробно затрагивающие отдельные ас- пекты истории Канадского корпуса в России. Это статья канадского и американского историка российского происхождения Л.И. Страховского, посвященная канадской артиллерийской бригаде на Севере России [20], и работа У. Мюррея «Сanadians in Dunsterforce», посвященную участию канадцев в боевых действиях в Южном и Западном Прикаспии [21-23]. Можно, наконец, назвать две главы, посвященные участию канадских войск в интервенции, в написанной Г.В.Л. Николсоном официальной истории участия канадских войск в Первой мировой войне [24, p. 510-524].

В отличие от предыдущих работ, следующая монография посвящена всей иностранной интервенции в Россию как таковой, хотя ее автор, как канадец, делает некоторый акцент именно на канадском участии. Это книга военного историка, отставного офицера ВМС Канады И. Моффата «The Allied Intervention in Russia, 1918-1920: The Diplomacy of Chaos» [25]. По мнению рецензента Л.Е. Флейка, это первая в зарубежной историографии попытка фундаментального исследования интервенции Антанты в Россию [26]. Во введении автор объясняет, почему выбрал для своей монографии именно такое название По его мнению, в межсоюзнических отношениях во время интервенции наблюдался именно хаос, полная неразбериха, так как державы Антанты часто не могли скоординировать свои действия против большевиков, руководствуясь не столько желанием победить общего врага, сколько собственными интересами, противоречившими друг другу [25, p. 1]. Моффат считает главной причиной этого хаоса то, что у Антанты в принципе не было большого опыта объединения сил нескольких государств под одним командованием (если не считать короткого периода 1918 г., когда главковерхом всех сил союзников на Западном фронте был маршал Фош) [25, p. 1]. Ученый считает, что разлад в стане союзников возник, во-первых, из-за претензий США на лидерство, не поддержанных другими странами Антанты, а также из-за стремления Японии закрепиться на оккупированной ею российской территории [25, p. 47-64]. Как и Айситт, Моффат выделяет две основные цели участия Канады в интервенции - добиться признания себя как независимой державы и получить контроль над торговым домом «Кунст и Альберс» [25, p. 4].

Представляет большой интерес тема общественного мнения Канады о событиях 1917-1922 гг. в России. Одним из первых этот вопрос поднял известный канадский коммунист, лидер Коммунистической партии Канады (КПК) Т. Бак, осветивший в своей работе «Canada and the Russian revolution» восприятие революции канадским рабочим классом [27]. Хотя Бак и не является историком по профессии, его книга написана вполне научным языком, снабжена ссылочным аппаратом и, по мнению автора данной статьи, может быть рассмотрена в ней - так как именно в ней был впервые поднят упомянутый вопрос об общественном мнении. Лидер канадских коммунистов пишет, что рабочие Канады горячо приветствовали Октябрьскую революцию. Большую роль в этом сыграл ленинский Декрет о мире. В это время в Канаде были широко распространены антивоенные настроения, вызванные нежеланием значительной части общества участвовать в Первой мировой войне, поэтому этот декрет был воспринят канадскими рабочими с энтузиазмом [27, р. 27]. Лидер 
КПК отмечает значительную популярность в Канаде и другой ленинской работы - «Письма к американским рабочим» [27, p. 37-38]. Наконец, Бак решительно осуждает канадскую интервенцию в Россию, критикуя планы правительства Р. Бордена по эксплуатации природных ресурсов Сибири, ставшие одной из причин интервенции [27, р. 43-44].

Более подробно общественное мнение Канады о Революции и Гражданской войне в России рассмотрела исследовательница Т. Бакстер в своей диссертации на степень магистра искусств «Selected aspects of Canadian public opinion on the Russian Revolution and its impact on Canada, 1917-1919», защищенной в 1972 г. в Университете Западного Онтарио [28]. В этой работе Бакстер анализирует восприятие событий Февральской и Октябрьской революций, а также иностранной интервенции депутатами Палаты общин [28, p. 3-16], ежедневной прессой [28, p. 16-55], церковной прессой [28, p. 55-95], профсоюзной прессой [28, p. 95-153], а также изданиями канадской интеллигенции (в основном университетскими журналами) [28, p. 153-188]. Также она рассматривает образ большевиков в восприятии указанных групп. Что интересно, под «большевиками» имеются в виду не только собственно члены РКП(б), но и канадские социалисты и профсоюзные активисты, вне зависимости от их отношения к большевизму. Так, организаторов Виннипегской всеобщей забастовки 1919 г. (местных профсоюзных активистов) автор работы именует «канадскими большевиками». Такая терминология неслучайна: в канадской печати того времени слово «большевик» часто использовалось как ругательное для обозначения людей левых взглядов.

Бакстер отмечает, что Февральскую революцию большинство канадских газет встретило с энтузиазмом. С революцией канадская пресса связывала надежды на демократизацию России и на то, что она станет более эффективным союзником Канады в войне с Германией. Лишь ряд церковных изданий и изданий интеллигенции опасались, что смена власти в России приведет к ее ослаблению и развалу армии $[28$, p. 58]. Что касается Октябрьской революции, то она вызвала резкое осуждение во всех рассмотренных Бакстер изданиях как переворот против законного правительства России. На страницах изданий резко критиковались как внешняя политика большевиков (Брестский мир), так и внутренняя политика (запрет оппозиции, репрессии, а также не имевшая место в реальности, но широко упоминаемая на Западе «национализация женщин»). Еще одним частым сюжетом канадской прессы был страх перед «красной угрозой»- возможным экспортом революции в другие страны, включая Канаду. Исключение здесь составила лишь рабочая пресса, с первых дней революции выразившая поддержку РСФСР. Правда, несмотря на поддержку Советского правительства, канадские социалисты позволяли себе и его критику, в частности за недемократические методы управления страной и «красный террор» [28, р. 103]. Бакстер отмечает, что действия правительства Р. Бордена, отправившего канадские войска в Россию, пользовались некоторой поддержкой только до конца 1918 г., когда шла Первая мировая война и интервенция воспринималась как вклад Канады в борьбу против немцев. После поражения Германии мотив борьбы с немцами потерял актуальность, после чего большинство изданий подвергли сомнению целесообразность нахождения канадских войск в России. Работа Т. Бакстер имеет большую научную ценность как единственная в своем роде работа, посвященная проблеме общественного мнения Канады о Революции и Гражданской войне в России.

Завершая разговор о канадской историографии, стоит коснуться еще одного пласта канадской историографии - статей иностранных исследователей, опубликованных в канадских научных журналах. Эти журналы - два ведущих научных издания Канады, публикующих работы по истории России: Canadian Historical Review и Canadian Slavonic Papers. Во-первых, это статья американского исследователя Т.Дж. Колтона «Military Councils and Military Politics in the Russian Civil War», посвященная отношениям между военными и партийными органами в Красной Армии. Колтон, в отличие от многих других исследователей, считает, что эти отношения были в общем нормальными. При этом он обращает внимание на противоречия, часто возникавшие между высшим командованием РККА и командирами отдельных частей, приводя в пример оборону Царицына [29]. Во-вторых, это работа американцев С.У. Пейджа и А. Эзергайлиса, посвященная роли латышских стрелков в Октябрьской революции. По мнению авторов, эта роль была ключевой, так как именно латышским воинским частям большевики обязаны успехом Октябрьского переворота [30]. Наконец, в-третьих, представляет интерес статья американцев А.Е. Зенна и Г. Голдберга, в которой авторы рассматривают различные версии убийства немецкого посла графа Мирбаха в 1918 году [31].

Итак, канадская историография испытывает стабильный интерес к событиям 1917-1922 годов в России. Историки Канады с одобрением пишут о Февральской революции, считая ее важным, пусть и неудачным, шагом России на пути к демократии. В то же время они, как правило, осуждают Октябрьскую революцию и критически относятся к большевикам, отмечая их радикализм, авторитаризм и нетерпимость к оппонентам. Еще один важный пункт критики большевиков - Брестский мир и связанные с его подписанием обвинения в прогерманской ориентации. Ряд авторов, в частности Н.Г.О. Перейра, видят корни большевизма в психологии русского народа, легко манипулируемого и нуждающегося в сильном авторитарном правителе. Белогвардейцев канадские авторы оценивают противоречиво: белые, как правило, удостаиваются некоторой симпатии как союзники Антанты, но их тем не менее критикуют - за разобщенность и непоследовательную внутреннюю политику.

По очевидным причинам, наиболее исследованным у канадских авторов аспектом Гражданской войны в России является история участия Канады в иностранной интервенции. Авторы всех рассмотренных работ солидарны в определении главных причин интервенции - они видят таковыми желание правительства Р. Бордена самоутвердиться на мировой арене и получить в свое распоряжение ресурсы Сибири. Канадские историки в большинстве своем осуждают участие Канады в интервенции как недопустимое вмешательство в дела иностранного государства.

В настоящее время степень изученности канадской историографии Революции и Гражданской войны в России, как уже отмечалось, далека от полноты. Одной из причин этого является то, что на русский язык пока переведены лишь две работы канадских 
авторов по этой теме. Тем не менее эта тема, безусловно, представляет научный интерес, и хочется надеяться на то, что число переводов канадских работ на русский в будущем вырастет, а сами эти работы привлекут интерес исследователей.

\section{Список литературы:}

1. Иоффе Г.3. Февральская революция 1917 года в англо-американской буржуазной историографии. М.: Наука, 1970. 260 с.

2. Неровный А.В. Зарубежная историография участия канадского военного контингента в интервенции на Русском Севере в 1918-1919 гг. // Ученые зап. Казан. ун-та. Сер. Гуманит. науки. 2017. Т. 159, кн. 4. C. $1004-1018$

3. Mavor J. The Russian Revolution. London: Routledge, 2016. $488 \mathrm{pp}$

4. Billington J. Six views of the Russian Revolution // World Politics. 1966. Vol. 18, № 3. P. 452-473.

5. Karpovich M. The Russian Revolution of 1917 // The Journal of Modern History. 1930. Vol. 2, № 2. P. 258-280.

6. Smeele J. The Russian Revolution and Civil War 1917-1921: An Annotated Bibliography. London \& New York: Continuum, 2003. 625 p.

7. Pereira N.G.O. White Siberia: The Politics of Civil War. Toronto \& Kingston: McGill-Queen' University Press, 1996. $261 \mathrm{p}$.

8. Минаева В.Ю. Историография Гражданской войны и иностранной интервенции в Забайкалье (к постановке проблемы) // Вестник Бурятского государственного университета. Педагогика. Филология. Философия. 2015, № 7. С. 230-235.

9. Pereira N.G.O. White Power during the Civil War in Siberia (1918-1920): Dilemmas of Kolchak's War Anti-Communism // Canadian Slavonic Papers. 1987. Vol. 29, № 1. P. 26-47.

10. Pereira N.G.O. Regional Consciousness in Siberia before and after October 1917 // Canadian Slavonic Papers. 1988. Vol. 30, № 1. P. 112-133.

11. Pereira N.G.O. The Idea of Regionalism in late Imperial and Revolutionary Russia // Russian History. 1993. Vol. 20, № 1/4. P. 163-178.

12. Pereira N.G.O. The Partisan Movement in Western Siberia, 1918-1920 // Jahrbücher für Geschichte Osteuropas. 1990. Bd. 38, h. 1. P. 87-97.

13. Pereira N.G.O. Siberian Atamanshchina: Warlordism in the Russian Civil War // The Bolsheviks in Russian Society: The Revolution and the Civil Wars / ed. by V. Brovkin. New Haven, CT: Yale University Press, 1997. P. 122-138.

14. Marples D. Motherland: Russia in the Twentieth Century. London: Routledge, 2014. 388 p.

15. Иоффе Г.3. «Долой Временное правительство!» (судьбы министров Временного правительства после падения Зимнего дворца) // Отечественная история. 2006. № 5. С. 109-116.

16. Иоффе Г.3. (Монреаль, Канада). Основные проблемы историографии Февральской революции в вопросах и ответах // Февральская революция 1917 года: проблемы истории и историографии: сб. докл. междунар. науч. конф. / отв. ред. проф. В.В. Калашников; под ред. Д.Н. Меньшикова. СПб.: Изд-во СПбГЭТУ «ЛЭТИ». С. 44-48.

17. Иситт Б. Из Виктории во Владивосток: Канадская Сибирская экспедиция 1917-1919 / Пер. с англ. С. Панич. Владивосток: Дальнаука, 2013. 392 с.

18. Еременко К.С. Канадский эпизод Гражданской войны в России (Рецензия на кн.: Иситт Б. Из Виктории во Владивосток: Канадская Сибирская экспедиция 1917-1919 / Пер. с англ. С. Панич. Владивосток: Дальнаука, 2013. 392 с.) // Канадский ежегодник. 2014. С. 145-148.

19. MacLaren R. Canadians in Russia 1918-1919. Toronto: Macmillan Can., 1976. 301 p.

20. Strakhovsky L. The Canadian Artillery Brigade in North Russia, 1918-1919 // Canadian Historical Review. 1958. Vol. XXXIX, № 2. P. 125-146.

21. Murray W. Canadians in Dunsterforce // Canadian Defense Quarterly. 1931. Vol. 8, № 2. P. 209-218.

22. Murray W. Canadians in Dunsterforce // Canadian Defense Quarterly. 1931. Vol. 8, № 3. P. 377-386.

23. Murray W. Canadians in Dunsterforce // Canadian Defense Quarterly. 1931. Vol. 8, № 4. P. 487-497.

24. Nickolson G.W.L. Canadians in Northern Russia. Intervention in Siberia // Canadian Expeditionary Force 1914-1919. Ottawa: Queen's Printer, 1962. P. 510-524.

25. Moffat I. The Allied Intervention in Russia, 1918-1920: The Diplomacy of Chaos. Berlin, Springer, 2016. $337 \mathrm{p}$.

26. Lincoln E. Flake. The Allied Intervention in Russia, 1918-1920: The Diplomacy of Chaos by Moffat, Ian C.D. // The Journal of Slavic Military Studies. 2016. Vol. 29, is. 1. P. 164-166.

27. Buck T. Canada and the Russian Revolution. Toronto: Progress Books, 1967. 98 p.

28. Buxter T. Selected aspects of Canadian public opinion on the Russian Revolution and its impact on Canada, 1917-1919. London: University of Western Ontario, 1972. $201 \mathrm{p}$.

29. Colton T.J. Military Councils and Military Politics in the Russian Civil War // Canadian Slavonic Papers. 1976. Vol. 18, is. 1. P. 36-57.

30. Page S.W., Ezergailis A. The Lenin-Latvian Axis in the November Seizure of Power // Canadian Slavonic Papers. 1977. Vol. 19, is. 1. P. 32-49.

31. Senn A.E., Goldberg J.H. The Assassination of Count Mirbach // Canadian Slavonic Papers. 1979. Vol. 21, is. 4. P. 438-445.

\section{THE REVOLUTION AND CIVIL WAR IN RUSSIA IN CANADIAN HISTORIOGRAPHY}

(C) 2019

Bandilet Sergey Viktorovich, postgraduate student of History and Archeology Department Far Eastern Federal University (Vladivostok, Russian Federation)

Abstract. This paper is devoted to perception of the February Revolution, the October revolution and the Civil War in Russia in Canadian historiography. The paper considers, firstly, works of historians - Canadian citizens, secondly, works of scientists from other countries who have worked in Canada for a long time and, thirdly, works of foreigners, who published in Canadian scientific journals. All of the above works can be divided into three groups. Firstly, these are fundamental works on the history of the Russian Revolution and Civil War. Secondly, these are works devoted to foreign intervention in Russia and Canadian participation of Canada in this intervention. Thirdly, these are works relating to other particular aspects of this subject. The authors of all considered works refer to the 
February Revolution as an important step for democracy in Russia. Canadian historiography mainly condemns the October Revolution and criticizes Bolsheviks for authoritarianism and radicalism. The attitude of Canadian scientists to the White Guards is ambiguous. On the one hand, there is a certain sympathy for the Whites as allies of the Entente (and Canada). But on the other hand, the Whites are condemned for their ill-conceived domestic policies and for inability to reach a compromise with each other. The Canadian historiography of the 1917-1922 events in Russia is now practically unexplored, and therefore it is of scientific interest.

Keywords: Canada; historiography; February revolution; October revolution; Bolsheviks; Civil War in Russia; Foreign military intervention in Russia; Entente; Canadian Siberian expedition; Canadian Siberian expedition corps; Siberia; Kolchak; Omsk government; Brest-Litovsk peace treaty.

$* * *$

УДК 94(9/4)

DOI 10.24411/2309-4370-2019-14218

Статья поступила в редакцию 30.05.2019

\section{ЭКОНОМИЧЕСКИЕ ПРОБЛЕМЫ И УГРОЗЫ СТАРОГО СВЕТА: ОЦЕНКИ ПРЕССЫ США} (C) 2019

Буранок Сергей Олегович, доктор исторических наук, доцент, профессор кафедры всеобщей истории, права и методики обучения

Беляева Катерина Вячеславовна, студент исторического факультета

Тулузакова Маргарита Игоревна, аспирант кафедры всеобщей истории, права и методики обучения Самарский государственный соииально-педагогический университет (2. Самара, Российская Федераиия)

Аннотация. В данной статье рассматривается эволюционный процесс формирования отношения средств массовой информации Соединенных Штатов Америки к Советской России во время массового голода начала 20-х годов XX века, известного как «голод в Поволжье». Новизна данного исследования заключается в анализе оценок голода 1921-1922 годов, которые были сделаны американскими журналистами. Авторы предоставляют результаты анализа различных американских газет на предмет формирования образа советской власти, советского народа и так называемой «красной угрозы» в связи с событиями того времени. Авторами был сделан обзор основных аргументов американской прессы, который выявил, что образ «голода в Поволжье» играл немаловажную роль в актуализации маркера «отсталой» страны по отношению к Советской России. Изучение данного информационного феномена позволит исследователям понять, какое воздействие на советско-американские отношения было оказано американскими средствами массовой информации через формирование представлений о России и российском/советском народе. Это, в свою очередь, может объяснить некоторые стереотипы восприятия России в американском общественном мнении как в прошлом, так и в настоящее время.

Ключевые слова: российско-американские отношения; «красная угроза»; образ России; пресса США; общественное мнение; последствия Гражданской войны; американские газеты; внешняя политика США; голод; американские журналисты; голод в Поволжье; New York Times; экономика Советской России.

Изучение образа угроз - новый подход в исторической имагологии: анализ не только общего образа Старого Света (на примере Советской России) в американском обществе, но и исследование конкретных практик и методик по его формированию на примере образа «угрозы голода», т.к. именно с помощью данного образа у общественности США актуализировались приоритетные черты восприятия России в межвоенный период. Кроме того, изучение данной темы будет способствовать выявлению новых фактов и источников по истории прессы США и внешней политики США.

Исследуемая проблема является актуальной для современного этапа развития исторической науки, так как она дает информацию к аналитическому осмыслению современных информационных процессов, протекающих в американском социуме. При этом необходимо подчеркнуть, что многие сформировавшиеся в период 1923-1939 гг. стереотипы восприятия Старого Света продолжали функционировать и на следующем историческом этапе - во время Второй мировой войны, оставаясь важной частью американского общественного сознания, проявляясь в том числе в качестве одного из основных элемен- тов социальной мифологии. Следовательно, требуется всестороннее изучение особенностей создания и функционирования образа Старого Света и экономических угроз в условиях и конкретно-исторической обстановке, складывавшихся по ходу межвоенного периода. Тема исследования подразумевает конструирование процесса формирования образа экономических угроз, который создавался в США в переломную эпоху: важно определить, какие новые черты и элементы появились в традиционном образе Старого Света в США в связи с формированием новой власти, новой идеологии и, как следствие этого, новой угрозы войны - из-за экономических проблем Европы и России. С другой стороны, образ Старого Света и его экономических проблем служил для американцев инструментом по корректировке собственного образа, своей идентичности и Я-концепции: Советская Россия становится важным элементом в системе самовосприятия американского общества - через сравнение процессов в России и США неизменно доказывалось экономическое, социально-политическое и духовное превосходство Америки и демократии в целом.

Таким образом, исследование образа Старого Света и угрозы голода, сформировавшегося в амери- 